\title{
Загальна характеристика показників ефективного еритропоезу та периферичної крові в активних донорів крові
}

\author{
YU. YU. DERPAK \\ Blood Transfusion Point of the South-Western Rail Way, Kyiv
}

\section{GENERAL DESCRIPTION OF INDICATORS AND EFFECTIVE ERYTHROPOIESIS PERIPHERAL BLOOD OF ACTIVE DONORS}

\begin{abstract}
Збереження здоров’я донорських кадрів є важливим завданням служби крові. Метою роботи було проведення комплексного дослідження показника ефективного еритропоезу та стану периферичної крові у первинних і активних донорів крові з метою виявлення можливих змін. Обстежено 148 донорів крові (105 чоловіків і 43 жінки), серед яких 102 активних донори (77 чоловіків і 25 жінок), які здають кров регулярно, не менше трьох разів на рік, і 46 первинних донорів резерву (29 чоловіків і 17 жінок), які здавали кров уперше. Первинні донори резерву склали контрольну групу. Вік обстежених активних донорів у середньому становив $(40,90 \pm 0,91)$ року, при індивідуальних коливаннях від 20 до 59 років. Установлено, що активне донорство не супроводжується змінами кількісного складу клітин периферичної крові. В активних донорів-жінок, які мали донорський стаж понад 10 років, мало місце достовірне збільшення показника ефективного еритропоезу порівняно із контрольною групою та середнім його значенням у групі активних донорів у цілому. Зроблено висновок, що є необхідність подальшого вивчення параметрів, які характеризують стан периферичної ланки еритропоезу в активних донорів для оптимізації моніторингу за станом їх здоров’я.

Saving donor health personnel is an important task of service blood. Purpose of the work was to conduct a comprehensive study indicator of effective erythropoiesis and peripheral blood condition in primary and active blood donors in order to identify possible changes. The study involved 148 donors (105 men and 43 women), among them - 102 active donors (77 men and 25 women) who give blood regularly, at least three times a year and 46 primary donor reserve (29 men and 17 women) who donated blood for the first time. Primary reserve donors in the control group. Age of active donors surveyed, the average was $(\mathbf{4 0 . 9 0 \pm 0 . 9 1 )}$ years, with individual variations from 20 to 59 years. It is established that active donor is not accompanied by quantitative changes of peripheral blood cells. In active female donors who had donor experience over 10 years, there had been a significant increase in the effective erythropoiesis compared to the control group and the average value of its active donors in the group as a whole. It is concluded that there is a need to further explore the parameters that characterize the state of erythropoiesis in the peripheral parts of active donors to optimize the monitoring of their health.
\end{abstract}

Постановка проблеми і аналіз останніх досліджень та публікацій. Донорство відносять до найважливіших розділів служби крові, без динамічного розвитку якого неможливо успішно розвивати такі напрямки спеціалізованої медичної допомоги, як хірургія, нейрохірургія, серцево-судинна та торакальна хірургія, реанімація, гематологія, акушерство і гінекологія, онкологія, травматологія тощо. Вербування і відбір донорів $€$ вирішальними факторами успішного проведення програми заготівлі крові. Необхідно докладати всіх зусиль для забезпечення безпеки як донора, так і реципієнта. Процес відбору донорів $є$ надійним за умови достовірності інформації, що від них отримують. Світовий досвід показує, що означена умова $€$ найвигіднішою, коли здавання крові є безоплатним. Проблем із відбором донорів стає менше, коли діяльність служби крові базується на принципах добровільності і відсутності матеріальної зацікавленості. Якщо донори оплачуються, їх можуть використовувати частіше регламентованих термінів, що збільшує вірогідність передавання захворювань. Вербування в ролі донорів членів сімей хворих (“сімейне” донорство) часто сприяє надмірному тиску з боку адміністрації лікувальних установ на такі сім'ї, що може викликати в останніх мотивацію найму за матеріальну винагороду інших людей замість справжніх родичів. Ризик передавання захворювань 3 компонентами і препаратами крові при проведенні трансфузії створює нові проблеми для здоров'я, диктує необхідність точного дотримання стандартів організа- 


\section{З ДОСВІДУ РОБОТИ}

ції донорства і впровадження суворого контролю якості за проведенням донації та наступними етапами роботи із отриманою кров’ю $[1-3,5,6]$.

Незважаючи на збільшення впродовж останнього часу кількості наукових досліджень щодо збереження здоров’я донорів, проблема комплексного врегулювання даного питання залишається невирішеною. Вивчали показники, що характеризують обмін заліза в організмі донорів та стан гліколітичних процесів в еритроцитах периферичної крові залежно від донорського стажу, вплив методів заготівлі та умов зберігання на якість свіжозамороженої плазми, стан здоров'я донорів на етапах донації плазми методом автоматичного плазмаферезу, питання оптимізації донорства та його медико-соціальні аспекти [1-4, 7, 8]. Залишається фрагментарно вивченою еритроцитарна ланка периферичної крові в активних донорів. Як показав проведений нами аналіз літератури, залишається невивченим і показник ефективного еритропоезу в первинних і активних донорів, що й спонукало нас до відповідних досліджень.

Мета роботи: провести комплексне дослідження показника ефективного еритропоезу і стану периферичної крові у первинних і активних донорів крові з метою виявлення можливих змін.

Матеріали і методи. Було обстежено 148 донорів крові (105 чоловіків і 43 жінки), серед яких 102 активних донори (77 чоловіків і 25 жінок), які здають кров регулярно, не менше 3 разів на рік, i 46 первинних донорів резерву (29 чоловіків і 17 жінок), які здавали кров уперше. Первинні донори резерву склали контрольну групу. Вік обстежених активних донорів у середньому становив $(40,90 \pm 0,91)$ року при індивідуальних коливаннях від 20 до 59 років. Середній вік донорів-чоловіків становив $(41,04 \pm 1,01)$ року, при індивідуальних коливаннях від 20 до 59 років. Середній вік донорів-жінок становив $(40,44 \pm 2,07)$ року, при індивідуальних коливаннях від 22 до 58 років.

У контрольній групі вік обстежених первинних донорів у середньому становив $(38,88 \pm 1,32)$ року, при індивідуальних коливаннях від 19 до 59 років. Середній вік донорів-чоловіків становив $(39,66 \pm 1,53)$ року, при індивідуальних коливаннях від 22 до 59 років. Середній вік донорів-жінок становив $(37,50 \pm 2,48)$ року, при індивідуальних коливаннях від 19 до 57 років.

Групи обстежених донорів однорідні за віковою і статевою структурою.

Усі донори були обстежені у Дорожній станції переливання крові Південно-Західної залізниці відповідно до вимог “Порядку медичного обстеження донорів крові та (або) її компонентів”, затвер- дженого наказом МОЗ України від 01.08.2005 р. за № 385 “Про інфекційну безпеку донорської крові та іiї компонентів”, як донори, кров яких використовується для виготовлення компонентів.

Перед здаванням крові донори проходили анкетування та медичний огляд кваліфікованими спеціалістами відповідно до вимог діючого “Порядку медичного обстеження донорів крові та (або) її компонентів”. У кожного донора визначали вміст гемоглобіну (норма: чоловіки - не менше 130 г/л, жінки - не менше 120 г/л). За результатами обстеження донорам визначали обсяг донації крові (максимально допустима доза - 450 мл, без урахування крові, вилученої для аналізів, об’ємом до 40 мл). Для активних донорів крові обов’язково враховували допустимий інтервал між подальшими донаціями крові, який не повинен бути меншим ніж 60 днів від дня попередньої донації, а також щорічну кількість донацій - не більше 5 для чоловіків та не більше 4 для жінок. Показник ефективного еритропоезу визначали за методикою Г. И. Козинца, Я. Х. Хакимовой, А. И. Быковой и соавт. (1988) [9]. Усі дані, одержані в результаті проведеного нами дослідження, були статистично оброблені. Для перевірки гіпотез щодо рівності генеральних середніх незалежних вибірок використовували t-критерій Стьюдента.

\section{Результати досліджень та їх обговорення.} Як ми вже згадували, групу первинних донорів склали 29 чоловіків і 17 жінок. Усі 46 первинних донорів були практично здорові i, за результатами анкетування, огляду спеціалістів та визначення вмісту гемоглобіну, допущені до здавання крові. Результати обстеження зданої крові на наявність маркерів гемотрансмісивних інфекцій були негативними. Вміст АлАТ не перевищував максимально допустимих значень.

Усім обстеженим первинним донорам у клінічній лабораторії Київського міського центру крові було зроблено розгорнутий аналіз периферичної крові, дані якого наведено у таблиці 1.

Із наведених у таблиці 1 даних видно, що концентрація гемоглобіну в групі первинних донорів у середньому становила $(138,88 \pm 6,91)$ г/л. При цьому даний показник в обстежених донорів-чоловіків у середньому становив $(142,72 \pm 4,60)$ г/л, при індивідуальних коливаннях від 135 до 150 г/л, а у жінок - $(132,06 \pm 3,77)$ г/л, при індивідуальних коливаннях від 127 до 140 г/л. Концентрація гемоглобіну в донорів-чоловіків була більша, ніж у донорів-жінок $(\mathrm{p}<0,001)$.

Кількість еритроцитів у групі первинних до-

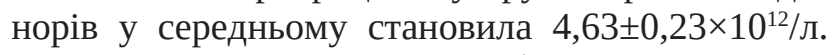
При цьому даний показник в обстежених донорів- 
Таблиця 1. Показники периферичної крові у первинних донорів (M+m)

\begin{tabular}{||c|c|c|c|c||}
\hline $\begin{array}{c}\text { Показник, } \\
\text { одиниця виміру }\end{array}$ & $\begin{array}{c}\text { Усі донори } \\
(\mathrm{n}=46)\end{array}$ & $\begin{array}{c}\text { Чоловіки } \\
(\mathrm{n}=29)\end{array}$ & $\begin{array}{c}\text { Жінки } \\
(\mathrm{n}=17)\end{array}$ & $\begin{array}{c}\text { Достовірність } \\
\text { різниці (p) }\end{array}$ \\
\hline Концентрація гемоглобіну, г/л & $138,88 \pm 6,91$ & $142,72 \pm 4,60$ & $132,06 \pm 3,77$ & $\mathrm{p}<0,001$ \\
\hline Кількість еритроцитів, $\times 10^{12} / л$ & $4,63 \pm 0,23$ & $4,76 \pm 0,15$ & $4,40 \pm 0,13$ & $\mathrm{p}<0,001$ \\
\hline Кількість лейкоцитів, $\times 10^{9} / л$ & $5,85 \pm 1,12$ & $5,85 \pm 1,01$ & $5,84 \pm 1,32$ & $\mathrm{p}>0,05$ \\
\hline Кількість тромбоцитів, $\times 10^{9} / л$ & $203,40 \pm 13,94$ & $204,38 \pm 15,23$ & $201,67 \pm 11,51$ & $\mathrm{p}>0,05$ \\
\hline \hline
\end{tabular}

Примітка. p - достовірність різниці між показниками залежно від статі.

чоловіків у середньому становив $4,76 \pm 0,15 \times 10^{12} /$ л, а в жінок - 4,40 $\pm 0,13 \times 10^{12} /$ л, при індивідуальних коливаннях у чоловіків - від 4,5 до $5,0 \times 10^{12} /$ л, а в жінок - від 4,2 до 4,7×10²/л. Кількість еритроцитів у донорів-чоловіків була більша, ніж у донорів-жінок $(\mathrm{p}<0,001)$.

Показник кількості лейкоцитів в обстежених донорів-чоловіків у середньому становив $5,85 \pm 1,01 \times 10 \%$ л, при індивідуальних коливаннях від 3,9 до 7,3×10\%/л, а в жінок -5,84 $\pm 1,32 \times 10^{9} /$ л, при індивідуальних коливаннях від 3,8 до 8,3×10\%/л. У цілому в групі первинних донорів кількість лейкоцитів становила $5,85 \pm 1,12 \times 10^{9} /$ л.

Кількість тромбоцитів у групі первинних донорів у середньому становила 203,40 $13,94 \times 10^{9} /$ л. При цьому даний показник в обстежених донорів-чоловіків у середньому становив 204,38 \pm $15,23 \times 10^{9} /$ л, а в жінок $-201,67 \pm 11,51 \times 10^{9} /$ л, при індивідуальних коливаннях у чоловіків - від 180 до $230 \times 10^{9} /$ л, а в жінок - від 190 до $220 \times 10^{9} /$ л.

Як видно з таблиці 1, в обстежених первинних донорів достовірної різниці між середніми значеннями показників кількості лейкоцитів і тромбоцитів залежно від статі не виявлено $(\mathrm{p}>0,05)$.

Як ми вже згадували, групу активних донорів склали 77 чоловіків і 25 жінок.

Усі 102 активних донори були практично здорові i, за результатами анкетування, огляду спеціалістів та визначення вмісту гемоглобіну, допущені до здавання крові. Результати обстеження зданої крові на наявність маркерів гемотрансмісивних інфекцій були негативними. Вміст АлАТ не перевищував максимально допустимих значень.

Дані розгорнутого аналізу периферичної крові активних донорів наводимо у таблиці 2.

Із наведених у таблиці 2 даних видно, що показник концентрації гемоглобіну в групі активних донорів у середньому становив $(138,60 \pm 8,36)$ г/л. При цьому даний показник в обстежених донорівчоловіків у середньому становив $(141,16 \pm 7,02)$ г/л, при індивідуальних коливаннях від 130 до 152 г/л, а в жінок - $(129,88 \pm 6,57)$ г/л, при індивідуальних коливаннях від 120 до 140 г/л. Середнє значення показника концентрації гемоглобіну в донорів-чоловіків було більшим, ніж у донорів-жінок $(\mathrm{p}<0,001)$. Ми не виявили достовірної різниці показників концентрації гемоглобіну в активних донорів та донорів контрольної групи (p>0,05).

Показник кількості еритроцитів у групі активних донорів у середньому становив $4,59 \pm 0,29 \times 10^{12} /$ л. При цьому даний показник в обстежених донорівчоловіків у середньому становив 4,67 $\pm 0,26 \times 10^{12} /$ л, а в жінок - 4,32 $\pm 0,21 \times 10^{12} /$ л, при індивідуальних коливаннях у чоловіків - від 4,2 до 5,0×10 12 /л, а в жінок - від 4,0 до 4,7×10²/л. Середнє значення показника кількості еритроцитів у донорів-чоловіків було більшим, ніж у донорів-жінок (р<0,001). Достовірної різниці середніх значень показників кількості еритроцитів в активних донорів та донорів контрольної групи нами не виявлено (р>0,05).

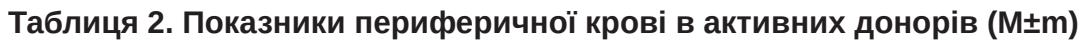

\begin{tabular}{||l|c|c|c|c||}
\hline \multicolumn{1}{|c|}{$\begin{array}{c}\text { Показник, } \\
\text { одиниця виміру }\end{array}$} & $\begin{array}{c}\text { Усі донори } \\
(\mathrm{n}=102)\end{array}$ & $\begin{array}{c}\text { Чоловіки } \\
(\mathrm{n}=77)\end{array}$ & $\begin{array}{c}\text { Жінки } \\
(\mathrm{n}=25)\end{array}$ & $\begin{array}{c}\text { Достовірність } \\
\text { різниці (p) }\end{array}$ \\
\hline $\begin{array}{l}\text { Концентрація } \\
\text { гемоглобіну, г/л }\end{array}$ & $138,60 \pm 8,36$ & $141,16 \pm 7,02$ & $129,88 \pm 6,57$ & $\begin{array}{c}\mathrm{p} 1<0,001 \\
\mathrm{p} 2>0,05\end{array}$ \\
\hline $\begin{array}{l}\text { Кількість } \\
\text { еритроцитів, } \times 10^{12} / л\end{array}$ & $4,59 \pm 0,29$ & $4,67 \pm 0,26$ & $4,32 \pm 0,21$ & $\begin{array}{c}\mathrm{p} 1<0,001 \\
\mathrm{p} 2>0,05\end{array}$ \\
\hline $\begin{array}{l}\text { Кількість } \\
\text { лейкоцитів, } \times 10^{9} / л\end{array}$ & $5,96 \pm 1,11$ & $5,92 \pm 1,11$ & $5,79 \pm 0,99$ & $\begin{array}{c}\mathrm{p} 1>0,05 \\
\mathrm{p} 2>0,05\end{array}$ \\
\hline $\begin{array}{l}\text { Кількість } \\
\text { тромбоцитів, } \times 10^{9} / л\end{array}$ & $203,65 \pm 15,57$ & $203,09 \pm 15,61$ & $201,20 \pm 15,90$ & $\mathrm{p} 1>0,05$ \\
$\mathrm{p} 2>0,05$
\end{tabular}

Примітка. р1 - достовірність різниці між показниками залежно від статі; р2 - достовірність різниці між показниками при порівнянні активних донорів крові з контрольною групою. 


\section{З ДОСВІДУ РОБОТИ}

Показник кількості лейкоцитів у обстежених донорів-чоловіків у середньому становив

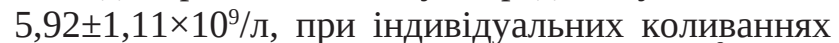
від 4,0 до 8,8×10\%/л, а в жінок - 5,79 $\pm 0,99 \times 10^{9}$ /л, при індивідуальних коливаннях від 4,0 до 7,3×109/л. У цілому в групі активних донорів кількість лейкоцитів становила 5,96 $1,11 \times 10^{9} / л$. Не виявлено достовірної різниці середніх значень показників кількості лейкоцитів в активних донорів залежно від статі (p>0,05) та при порівнянні з контрольною групою ( $>0,05)$.

Показник кількості тромбоцитів у групі активних донорів у середньому становив 203,65 $15,57 \times 10 \%$ л. При цьому даний показник в обстежених донорів-чоловіків у середньому становив

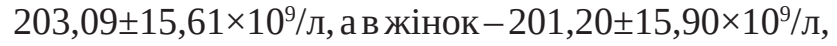
при індивідуальних коливаннях у чоловіків - від 180 до 240×10\%/л, а в жінок - від 180 до 230×10\%/л. Ми не виявили достовірної різниці середніх значень показників кількості тромбоцитів в активних донорів залежно від статі (p>0,05) та при порівнянні з контрольною групою (p>0,05).

Встановлено, що показник ефективного еритропоезу в контрольній групі становив 0,07士 $0,001 \times 10^{12} /$ л. Він демонструє, що саме така кількість еритроцитів утворюється і виходить в один літр периферичної крові щодоби. Ми не отримали статистично достовірних відмінностей даного показника в активних донорів порівняно з первинни-

\section{СПИСОК ЛІТЕРАТУРИ}

1. Гойда Н. Г. Особливості стану здоров’я і фізичного розвитку потенційних донорів молодого віку / Н. Г. Гойда, В. В. Грубляк // Східноєвропейський журнал громадського здоров’я. - 2009. - № 3 (7). - С. 42-47.

2. Гойда Н. Г. Соціально-демографічна характеристика донорів у деяких регіонах України (Хмельницькій, Чернівецькій, Рівненській областях) / Н. Г. Гойда, В.В.Грубляк // Україна. Здоров’я нації. - 2009. - № 3 (11). - С. 101-106.

3. Грубляк В. В. Соціальна характеристика потенційних донорів молодого віку / В. В. Грубляк // Східноєвропейський журнал громадського здоров’я. - 2009. - № 4 (8). - С. 154-159. 4. Видиборець С. В. Донорство крові та метаболізм заліза / С. В. Видиборець, Ю. Ю. Дерпак, О. В. Сергієнко. - ВінницяБориспіль : ТОВ “Меркьюрі-Поділля”, 2013. - 144 с.

5. Любчак В. В. Ефективність кадрового донорства в забезпеченні інфекційної безпеки донорства крові, її компонентів та препаратів / В. В. Любчак // Вісник соціальної гігієни та ми (p>0,05). Але поглиблене вивчення показника ефективного еритропоезу в активних донорів залежно від донорського стажу та кількості щорічних донацій дозволило встановити, що в активних донорів-жінок, які мали донорський стаж понад 10 років, мало місце достовірне збільшення даного показника порівняно 3 контрольною групою та середнім його значенням у групі активних донорів у цілому (р>0,05). Можна зробити припущення, що такі зміни показника ефективного еритропоезу в активних донорів-жінок, які мали донорський стаж понад 10 років, зумовлені фізіологічними особливостями жіночого організму в умовах постійного стимулювання еритропоезу за рахунок регулярних донацій.

Висновки. 1. Активне донорство не супроводжується змінами кількісного складу клітин периферичної крові.

2. В активних донорів-жінок, які мали донорський стаж понад 10 років, мало місце достовірне збільшення показника ефективного еритропоезу порівняно із контрольною групою та середнім його значенням у групі активних донорів у цілому.

3. Отримані дані диктують необхідність подальшого вивчення параметрів, що характеризують стан периферичної ланки еритропоезу в активних донорів для оптимізації моніторингу за станом їх здоров’я.

організації охорони здоров’я. - 2012. - № 1. - С. 86-89. 6. Любчак В. В. Менеджмент донорства як шлях раціонального використання ресурсів і складова управління якістю та забезпеченням інфекційної безпеки донорства крові, її компонентів та препаратів / В. В. Любчак, А. С. Тимченко, В. П. Любчак // Гематологія і переливання крові : міжвідомчий зб. - 2014. - Вип. 37. - С. 301-311.

7. Сергієнко О. В. Комплексна оцінка основних показників гліколізу в еритроцитах первинних донорів крові / О. В. Сергієнко // Збірник наукових праць співробітників НМАПО імені П. Л. Шупика. - 2010. - Вип. 19, кн. 3. - С. 283-287.

8. Сергієнко О. В. Особливості гліколізу в еритроцитах активних донорів крові / О. В. Сергієнко // Світ медицини та біології. - 2010. - № 3. - С. 38-40.

9. Цитологические особенности эритрона при анемиях / [Г. И. Козинец, Я. Х. Хакимова, А. И. Быкова и др.]. - М. : Медицина, 1988. - С. 15-16. 